\title{
ERP-Based Accounting Information System Implementation in Organization: A Study in Riau, Indonesia
}

\author{
Emrinaldi NUR D.P. ${ }^{1}$, Muhammad IRFAN ${ }^{2}$
}

Received: September 01, 2020 Revised: October 26, 2020 Accepted: November 05, 2020

\begin{abstract}
In the accounting information system implementation, the users should consider the benefits and advantages of the system. This paper examines the effect of the Enterprise Resources Planning based (ERP-based) accounting information system implementation on user impact and organizational impact. The population in this study is companies listed on the Indonesian Stock Exchange, especially companies based in Riau, Indonesia. These companies currently use the ERP-based accounting information system. Research samples are employees who use the ERP-based accounting information system. For data analysis, we use structural equation modeling (SEM). Based on data analysis, high-quality information system implementation generate high-quality information that can give satisfaction to the user. Moreover, the information system is related to user skill, satisfaction, and knowledge sharing which improve personal skills; enhanced personal skill contributes to organizational performance. On the other hand, there is no effect of training on personal skills and there is no effect of information quality on perceived usefulness. This research gives implication to the organization for implementing a high-quality ERP-based accounting information system that positively impacts organizational performance. Future research is expected to examine information system implementation in different research objects and conditions.
\end{abstract}

Keywords: ERP-Based Accounting Information System, Organizational Impact, User Impact

JEL Classification Code: M15, M41, O33

\section{Introduction}

Organizations have to make an effective strategy to achieve their goals, such as an information system implementation strategy. An information system is needed to support strategic and operational activities (Hutahaean, 2014) as well as daily decision-making (Susanto, 2013). The information system keeps growing in years. Hilbert and Lopez (2011) identify the exponential pace of technological change. Machines' application-specific capacity to compute information per capita roughly doubled every 14 months

${ }^{1}$ First Author and Corresponding Author. Lecturer, Department of Accounting, Faculty of Economics and Business, University of Riau, Indonesia [Postal Address: Kampus Bina Widya KM. 12,5, Simpang Baru, Kec. Tampan, Kota Pekanbaru, Riau 28293, Indonesia]

Email: emrinaldinur@lecturer.unri.ac.id

${ }^{2}$ Faculty of Economics and Business, University of Riau, Indonesia. Email: cp.irfaan@gmail.com

(C) Copyright: The Author(s)

This is an Open Access article distributed under the terms of the Creative Commons Attribution Non-Commercial License (https://creativecommons.org/licenses/by-nc/4.0/) which permits unrestricted non-commercial use, distribution, and reproduction in any medium, provided the original work is properly cited. between 1986 and 2007. The information system consists of 4 eras of development, which are the pre-mechanical era, mechanical era, electromagnetic era, and electronic era (Cash et al., 1992).

Hall (2010) explains that information system implementation failure is a result of conflict between organizational culture and information system implementation objectives. Information system improvement should decrease any errors and provides rapid work set to generate relevant and accurate information. Susanto (2013) also explains the information system is a tool to support daily activities, decision-making, and organization management to achieve business goals.

The information system needs support from hardware, software, and human resources system. Susanto (2013) suggests that the role and participation of system users determine the development of information system methods and technology. User role is important to make information system effective and efficient. Information system quality also gives a significant impact on use and user satisfaction (DeLone \& McLean, 2003). Information system quality can be seen by how fast the system (in this case, it refers to an ERP-based accounting information system) can process the accounting data into useful information (DeLone \& 
McLean, 2003). Alter (1996) also explains that information output is an indicator of information system performance. Information system quality is determined by service quality. Service quality refers to the ability of the service to meet user expectations (Kaihatu et al., 2015). Management of information system services factors leads to superior performance to generate reliable, accurate, and real-time information; further, it promotes effectiveness that can bring a significant contribution to the organization (Subiyanto, 2000).

A high-quality information system needs high-quality users. When a high-quality user is satisfied, then it indicates that information system quality is high as well. Gupta (2000) explains that information system user satisfaction is one of the indicators of information system effectiveness. The top information system level that can integrate all data and information management is Enterprise Resources Planning (ERP). ERP is a system between organizational function areas that run by an integrated software module to support the internal business process (Monk \& Wagner, 2013; O'Brien $\&$ Marakas, 2011). It allows the organization to provide an automated and integrated core business process. Krigsman (2011) finds that the success rate of ERP implementation is still low where $57 \%$ of ERP implementation needs more loading time, $57 \%$ of ERP implementation is out of budget, $41 \%$ of ERP users are failing to enjoy, $50 \%$ of ERP implementation benefits and $40 \%$ of ERP implementation leads to operational error. Also, 32\% of executives and 39\% of employees are not satisfied with ERP implementation since it contributes to $30 \%$ to $70 \%$ of project failure.

One of the technology-based information system implementations is Enterprise Resources Planning-based (ERP-based) accounting information system implementation. When an organization implements an ERP-based accounting information system, an organizational impact will occur. ERP-based accounting information system implementation might decrease employee productivity because system user satisfaction becomes lower when the old system is changed by a new one. Organizations can also experience ERP-based accounting information system implementation failure because of incompatible software on business processes and information (Lucas et al., 1988).

Seddon and Kiew (1996), Iivari (2005), Wu and Wang (2007), and Istianingsih and Wijayanto (2008) found accounting information system quality affects perceived usefulness, further, perceived usefulness affects user satisfaction. Iivari (2005), Tjakrawala and Cahyo (2010), and Gorla et al. (2010) found that information system quality affects the individual factors. Falgenti and Pahlevi (2013), Bokhari (2005), and Widodo et al. (2013) confirmed the success of the information system is determined by the relationship between information system quality, user satisfaction, and organizational impact. This research aims to examine the implementation of ERP-based accounting information systems and the consequences to the organization.

\section{Literature Review}

\subsection{Contingency Theory}

Contingency theory explains that the design and implementation of a management control system are determined by the context of the contingency variable where system operation is needed to be adjusted with organization conditions (Rahman et al., 2007; Tran et al., 2020). Otley (1980) also explains that the context factors are related to organizational needs and conditions. This research is based on contingency variables by Otley (1980) where the performance measurement system is needed to be generalized by considering organizational and situational variables, such as individual behavior.

\subsection{Technology Acceptance Model}

In the information system implementation, the users should consider the system's benefits and advantages. It can be captured by the technology acceptance model. The technology acceptance model provides the framework to investigate the impact of external variables on beliefs, personal abilities, attitude, mindset, motivation, and intention in information technology acceptance (Davis, 1989).

\subsection{Information System Implementation and Quality}

DeLone and Mclean (1992) explain accounting information system quality as information system performance; it includes hardware, software, and policy and procedures. All elements and sub-elements of the accounting information system are an indicator of information system quality determinant factor to generate high-quality information (Susanto, 2013). Information system service quality refers to the expected excellence and control to meet user expectations (Xu et al., 2013). Excellent information system management leads to reliable, accurate, real-time, and effective information system services that can bring sufficient contribution to the organization (Subiyanto, 2000). Service quality cannot be determined by the service provider but by the user (Kaihatu et al., 2015). The user has the authority to decide if the service is consistent with the expectation. Information system service quality focuses on information system performance (DeLone \& McLean, 1992). A high-quality information system generates high- 
quality information. Attributes of information quality are obtained from a system where it attaches with information accuracy, timeliness, relevance, and completeness (DeLone $\&$ McLean, 1992). Information quality is the key factor to determine user satisfaction (Doll et al., 1994). High-quality information provides accuracy, rapidity, completeness, and compatibility to fulfill management needs (Susanto, 2013). Complete, accurate, relevant, and real-time information can be achieved by a computerized system (Alannita \& Suaryana, 2014).

User characteristics are also important for the evaluation of information system implementation. It includes perceived usefulness, user satisfaction, and personal skill. Perceived usefulness is an indicator of an individual where he/she believes the information system can increase performance and accuracy. Besides, real-time, reliable information system output can increases the information system user trust (Davis, 1989). It also refers to a belief in performance improvement that comes from technology implementation (Tjini \& Baridwan, 2013). User participation is important to determine the information system implementation (Haddon, 2016). The user who contributes to effective and efficient information system implementation contributes to the organization's effectiveness and efficiency. User satisfaction is the result of their attitude on information system implementation (Miss, 2014). User satisfaction comes from service quality, system quality, and information quality (Martono et al., 2020). User satisfaction can lead to personal skills. Personal skill refers to the level of experience and ability that the user gains by using technology. It includes knowledge of the conceptualization of information systems (Simkin et al., 2015).

The user gains personal skills from knowledge sharing and training, as well. Knowledge sharing is various knowledge that the user gets from social interaction which involves knowledge, experience, and skill between employees (Pramono \& Susanty, 2016) by using various media (Triana et al., 2016), further, it improves their competence. Training refers to the effort to increase employees' performance in their current works (Bernardin \& Russell, 1998). In the context of information system implementation, user training is important to make information system implementation succeed (Pearlson et al., 2016). Since user contribution is important to value creation, the organization needs to formulate an extensive training program to ensure that users can use information technology effectively.

\subsection{Hypotheses}

DeLone and McLean (1992) explain that information system quality focuses on system performance include software, policy, and procedure to produce the needed information. Shannon (1948) also suggests the technical output level is an indicator of information system quality. The technical output level is occurred by the accuracy and efficiency of the communication system that generates information. Information quality refers to data processing that gives useful information to the user (Davis, 1989). High-quality information has to meet the completeness, relevance, accuracy, and timeliness elements (Alannita \& Suaryana, 2014). It needs a high-quality information system. A high-quality information system delivers high-quality information.

H1: Information system quality has an effect on information quality

Service quality refers to the user perception of the service provided by the information system program. Service quality captures the differences between expectation and perception related to the service (Parasuraman et al., 1985). Good service management can bring reliable, accurate, real-time, and effective information and give value to the organization (Subiyanto, 2000). High-quality service of information system implementation creates high-quality output that gives benefit to the user.

\section{H2: Service quality has an effect on information quality}

DeLone and McLean (1992) suggest software that has relatively high quality to provide satisfaction to the information system user since low-quality software promotes poor performance. User satisfaction is an indicator of information system success (Xiao \& Dasgupta, 2002). Istianingsih and Wijanto (2008) and Tjakrawala and Cahyo (2010) found that information system quality has a positive effect on information system user satisfaction. When the information system provides high-quality performance, the user feels satisfied because they can get the expected result.

H3: Information system quality has an effect on user satisfaction

Service quality captures the user's perception of the service. In the beginning, service quality determines customer satisfaction. Parasuraman et al. (1985) define service quality as the comparison between customer expectation and their perception about the given service. Watson et al. (1998) studied about service quality in the information system. Service quality holds an important role to support information system success. A high-quality information system without high-quality service will give no benefits. The main objective of the service is to give 
easiness, comfort, and satisfaction to the user. The equality between information systems and service qualities can bring satisfaction for the information system user..

\section{H4: Service quality has an effect on user satisfaction}

New or current employees have to be trained about basic skills related to their job. The training aims to increase employees' ability and skill. Medina et al. (2014) find that training increases employees' performance and satisfaction with information system implementation. Since the main objective of the training is employees' knowledge and competence upgrade, training can be implemented to improve personal skills.

\section{H5: training has an effect on personal skill}

Various knowledge and innovations are an important element to improve sustainable competitive advantage (Liao, 2006). Knowledge of information systems, or other non-information systems, can help the information system user (Choi et al., 2010; Liao, 2006). The organization has to improve information system performance continuously to maintain its competitive advantage. Performance improvement can be achieved with strong innovation. Liao (2006) found a significant relationship between organizational knowledge sharing and innovation but does not involve information technology factors. Choi et al. (2010) found a significant relationship between information technology supporting systems, knowledge sharing, and teamwork performance but do not involve strong innovation. Knowledge sharing supports individuals and groups to improve their performance.

\section{H6: Knowledge sharing has an effect on personal skill}

Information quality is a picture of the output quality of the information system (Rai et al., 2002). It refers to the data which have been proceeded by the system (Davis, 1989). Indicators of information quality are reliability, completeness, relevance, accuracy, and real-time (Alannita $\&$ Suaryana, 2014). High-quality information provides high usefulness. It can fulfill user needs. Rivard et al. (1997), Roldán and Leal (2003), and Istianingsih and Wijanto (2008) find information quality increases perceived usefulness. If the system generates high-quality information, it will be useful to the user.

H7: Information quality has an effect on perceived usefulness

Since high-quality information provides high usefulness to the user, information quality also can bring satisfaction to the user. The more useful the information, the more accurate decision will be made. Useful information gives user satisfaction with regard to output and information system performance. Seddon and Kiew (1996) find that information quality increases user satisfaction since highquality information meets user expectations.

\section{H8: Information quality has an effect on user satisfaction}

The model of DeLone and McLean (1992) explains that user satisfaction comes from the useful information system. The model of Seddon (1997) also hypothesizes that the useful information system brings higher user performance and satisfaction. The user perception of the system depends on how useful the system can be. The benefit of an information system will give a positive impact on the user. When the user feels that the information system is useful, they will be satisfied. Istianingsih and Wijanto (2008) and Tjakrawala and Cahyo (2010) find that perceived usefulness increases user satisfaction.

H9: Perceived usefulness has an effect on user satisfaction

Seddon (1997) explains performance as user perception on a specific application system used to increase their performance in an organization. An information system can give individual impact where the user believes the information system can increase their competence (Davis, 1989). Improvement of user ability can be achieved when the user is satisfied with the information system implementation (Miss, 2014). Satisfaction will give impact to the working process where the user will be motivated to increase their skill.

H10: perceived usefulness has an effect on personal skill

Information system implementation can bring potential to the user's ability and skill (Nurlina et al., 2020) where the user can get more working knowledge and generate a better working career in an organization (Gelinas et al., 2011). Seddon (1997), Davis (1989), DeLone and McLean (1992), Tjakrawala and Cahyo (2010), and Widodo et al. (2013) find that personal skill increases organizational impact. Optimal skills can provide optimal decision making and open the business prospect for the organization.

H11: Personal skill has an effect on organizational impact

In this research, eleven hypotheses explain information system implementation, its output, user impact, and organizational impact. As the bigger picture, it can be seen in the research framework as in figure 1. 


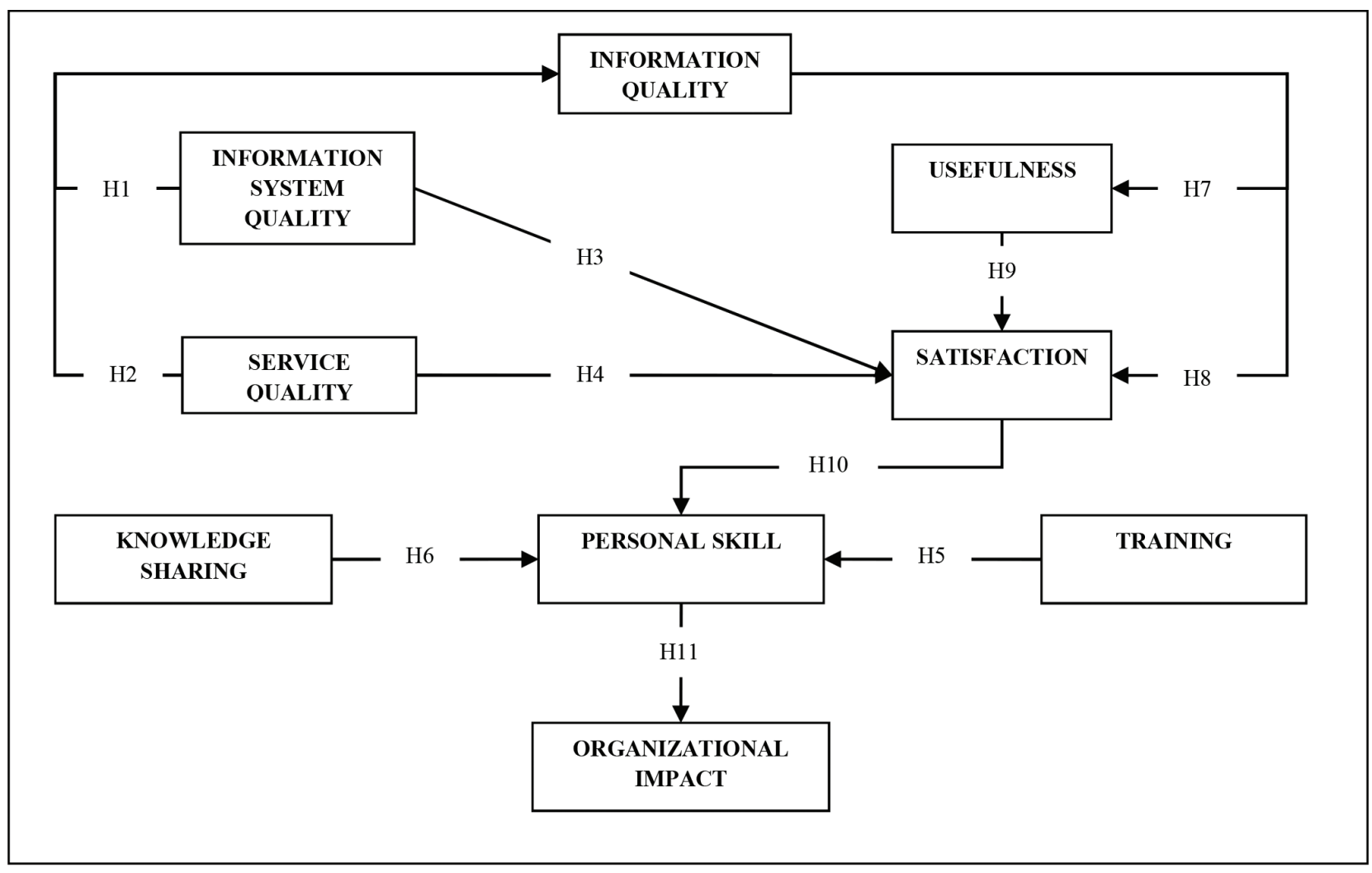

Figure 1: Research Framework

\section{Research Methods}

The population in this research is companies listed on the Indonesian Stock Exchange, especially companies based in Riau, Indonesia. These companies currently use the ERPbased accounting information system. Research samples are employees who use the ERP-based accounting information system. For data analysis, we use structural equation modeling (SEM). Hypotheses test is examined by path analysis.

\section{Results}

\subsection{Normality Test}

Table 1 shows the value of c.r. in multivariate analysis is 1.163 (below 2). It indicates that research data is distributed normally. The data analysis can continue to the next stage of SEM analysis.

\subsection{Validity and Reliability}

The validity test aims to ensure questionnaires can measure the variables, while the reliability test aims to ensure questionnaires are consistent. Questionnaires are valid if the value of the average variance extracted (AVE) is above 0.50 while questionnaires are reliable if the value of construct reliability is above 0.708 (Hair et al., 2010). The result of validity and reliability can be seen in table 2 .

Table 2 shows that the value of the AVE for all variables is above 0.50. It indicates that questionnaires are valid. The value of construct reliability for all variables is above 0.708 . It indicates that questionnaires are reliable.

\subsection{Confirmatory Analysis}

The confirmatory analysis is a model fitness examination that includes exogenous and endogenous variables confirmatory analysis. Model fitness analysis uses chisquare, probability, RMSEA, GFI, CFI, TLI, and CMIN/DF.

The exogenous confirmatory analysis is built by a total of 25 indicators for 4 exogenous variables (information system quality, service quality, training, and knowledge sharing). Table 3 shows that value of chi-square is 563.614 with probability 0.000 (below 0.05 ), value of RMSEA is 0.072 (below 0.08), value of GFI is 0.674 (below 0.90 ), value of CFI is 0.568 (below 0.95), and value of AGFI is 0.683 (below $0.95)$. The result indicates that indicators are acceptable for exogenous constructs. 
Table 1: Normality Test

\begin{tabular}{|c|c|c|c|c|c|c|c|}
\hline Variable & Question & $\min$ & $\max$ & skew & c.r. & kurtosis & c.r. \\
\hline \multirow[t]{6}{*}{ Training } & 6 & 2 & 5 & -0.764 & -3.679 & 0.791 & 1.903 \\
\hline & 5 & 2 & 5 & -0.286 & -1.375 & 0.001 & 0.003 \\
\hline & 4 & 2 & 5 & -0.585 & -2.817 & 0.88 & 2.117 \\
\hline & 3 & 2 & 5 & -0.594 & -2.858 & 0.276 & 0.664 \\
\hline & 2 & 2 & 5 & -0.502 & -2.417 & 0.263 & 0.633 \\
\hline & 1 & 2 & 5 & -0.262 & -1.26 & -0.181 & -0.434 \\
\hline \multirow[t]{6}{*}{ Knowledge Sharing } & 6 & 2 & 5 & -0.456 & -2.196 & -0.092 & -0.221 \\
\hline & 5 & 2 & 5 & -0.717 & -3.452 & 1.17 & 2.815 \\
\hline & 4 & 2 & 5 & -0.495 & -2.384 & 0.693 & 1.668 \\
\hline & 3 & 1 & 5 & -0.995 & -4.788 & 2.083 & 5.013 \\
\hline & 2 & 2 & 5 & -0.418 & -2.01 & 0.256 & 0.615 \\
\hline & 1 & 1 & 5 & -1.118 & -5.381 & 2.454 & 5.907 \\
\hline \multirow[t]{3}{*}{ Organizational Impact } & 1 & 3 & 5 & 0.051 & 0.245 & 0.378 & 0.908 \\
\hline & 2 & 3 & 5 & -0.09 & -0.432 & -0.576 & -1.386 \\
\hline & 3 & 3 & 5 & 0.01 & 0.05 & -0.051 & -0.123 \\
\hline \multirow[t]{4}{*}{ Personal Skill } & 1 & 2 & 5 & -0.221 & -1.065 & 0.615 & 1.479 \\
\hline & 2 & 3 & 5 & 0.038 & 0.185 & -0.264 & -0.635 \\
\hline & 3 & 1 & 5 & -1.174 & -5.652 & 1.605 & 3.675 \\
\hline & 4 & 2 & 5 & -0.424 & -2.043 & 0.68 & 1.637 \\
\hline \multirow[t]{5}{*}{ Service Quality } & 5 & 2 & 5 & -0.304 & -1.463 & 0.028 & 0.067 \\
\hline & 4 & 1 & 5 & -1.162 & -5.593 & 1.681 & 3.859 \\
\hline & 3 & 2 & 5 & -0.383 & -1.842 & -0.318 & -0.766 \\
\hline & 2 & 3 & 5 & -0.102 & -0.49 & -0.475 & -1.143 \\
\hline & 1 & 2 & 5 & -0.236 & -1.137 & 0.437 & 1.053 \\
\hline \multirow[t]{5}{*}{ Perceived Usefulness } & 1 & 1 & 5 & -0.39 & -1.875 & -0.059 & -0.143 \\
\hline & 2 & 2 & 5 & -0.456 & -2.196 & 0.413 & 0.994 \\
\hline & 3 & 3 & 5 & 0.038 & 0.184 & 0.383 & 0.922 \\
\hline & 4 & 2 & 5 & -0.205 & -0.984 & 0.33 & 0.794 \\
\hline & 5 & 2 & 5 & -0.186 & -0.897 & 0.398 & 0.958 \\
\hline \multirow[t]{6}{*}{ Information Quality } & 1 & 1 & 5 & -0.817 & -3.935 & 2.149 & 5.171 \\
\hline & 2 & 1 & 5 & -1.137 & -5.472 & 2.18 & 5.246 \\
\hline & 3 & 2 & 5 & -0.268 & -1.288 & -0.171 & -0.412 \\
\hline & 4 & 2 & 5 & -0.494 & -2.376 & 0.334 & 0.804 \\
\hline & 5 & 2 & 5 & -0.537 & -2.584 & 0.245 & 0.59 \\
\hline & 6 & 1 & 5 & -0.703 & -3.382 & 0.748 & 1.801 \\
\hline \multirow[t]{5}{*}{ User Satisfaction } & 1 & 2 & 5 & -0.125 & -0.602 & -0.208 & -0.5 \\
\hline & 2 & 2 & 5 & -0.475 & -2.287 & 0.958 & 2.306 \\
\hline & 3 & 2 & 5 & -0.446 & -2.144 & -0.074 & -0.178 \\
\hline & 4 & 2 & 5 & -0.561 & -2.698 & 0.493 & 1.187 \\
\hline & 5 & 2 & 5 & -0.5 & -2.405 & 0.343 & 0.826 \\
\hline \multirow[t]{8}{*}{ System Information Quality } & 1 & 1 & 5 & -1.196 & -5.755 & 2.259 & 5.437 \\
\hline & 2 & 1 & 5 & -1.041 & -5.012 & 1.469 & 3.536 \\
\hline & 3 & 1 & 5 & -0.602 & -2.896 & 0.482 & 1.159 \\
\hline & 4 & 1 & 5 & -0.954 & -4.591 & 1.249 & 3.006 \\
\hline & 5 & 1 & 5 & -0.745 & -3.586 & 0.347 & 0.835 \\
\hline & 6 & 1 & 5 & -0.938 & -4.515 & 0.861 & 2.072 \\
\hline & 7 & 1 & 5 & -0.755 & -3.633 & 0.234 & 0.564 \\
\hline & 8 & 1 & 5 & -0.749 & -3.605 & 0.311 & 0.747 \\
\hline Multivariate & & & & & & 31.197 & 1.163 \\
\hline
\end{tabular}


Table 2: Validity and Reliability

\begin{tabular}{|l|c|c|}
\hline Variable & $\begin{array}{c}\text { Average Variance } \\
\text { Extracted }\end{array}$ & $\begin{array}{c}\text { Construct } \\
\text { Reliability }\end{array}$ \\
\hline $\begin{array}{l}\text { Information } \\
\text { System Quality }\end{array}$ & 0.62241093 & 0.910427 \\
\hline Service Quality & 0.648727524 & 0.863934 \\
\hline Training & 0.643107689 & 0.908347 \\
\hline $\begin{array}{l}\text { Knowledge } \\
\text { Sharing }\end{array}$ & 0.715937963 & 0.929139 \\
\hline $\begin{array}{l}\text { Information } \\
\text { Quality }\end{array}$ & 0.676060525 & 0.922586 \\
\hline $\begin{array}{l}\text { Perceived } \\
\text { Usefulness }\end{array}$ & 0.620079672 & 0.881545 \\
\hline User Satisfaction & 0.632440511 & 0.885259 \\
\hline Personal Skill & 0.55478239 & 0.720359 \\
\hline $\begin{array}{l}\text { Organizational } \\
\text { Impact }\end{array}$ & 0.724564237 & 0.931717 \\
\hline
\end{tabular}

Table 3: Exogenous and Endogenous Confirmatory Model

\begin{tabular}{|l|c|c|}
\hline \multirow{2}{*}{ Indicator } & \multicolumn{2}{|c|}{ Value } \\
\cline { 2 - 3 } & $\begin{array}{c}\text { Exogenous } \\
\text { Variable }\end{array}$ & $\begin{array}{c}\text { Endogenous } \\
\text { Variable }\end{array}$ \\
\hline $\begin{array}{l}\text { Degree of Freedom } \\
\text { (DF) }\end{array}$ & 269 & 225 \\
\hline Chi-Square & 563.614 & 407.903 \\
\hline Probability & 0.000 & 0.000 \\
\hline GFI & 0.674 & 0.922 \\
\hline RMSEA & 0.072 & 0.071 \\
\hline AGFI & 0.683 & 0.946 \\
\hline CFI & 0.568 & 0.804 \\
\hline
\end{tabular}

The endogenous confirmatory analysis is built by a total of 23 indicators for 5 endogenous variables. Table 3 shows that value of chi-square is 407.903 with probability 0.000 (below 0.05), value of RMSEA is 0.071 (below 0.08), value of GFI is 0.992 (above 0.90), value of CFI is 0.860 (below 0.95 ), and value of AGFI is 0.924 (below 0.95). The result indicates that indicators are acceptable for endogenous constructs.

SEM analysis aims to examine the structural relationship between variables. The model has to be fit with variables and data. The result of the fitness model can be seen in table 4.
Table 4: Goodness-of-Fit Test

\begin{tabular}{|l|c|c|c|}
\hline $\begin{array}{l}\text { Goodness-of- } \\
\text { Fit Index }\end{array}$ & Cut off Value & Result & Notes \\
\hline $\begin{array}{l}\text { Degree of } \\
\text { Freedom (DF) }\end{array}$ & Positive (+) & 1063 & Good \\
\hline Chi-Square & $\begin{array}{c}\text { Expected to be } \\
\text { small }\end{array}$ & 783.570 & Good \\
\hline Probability & Above 0.05 & 0.071 & Good \\
\hline CMIN/DF & Below 2.00 & 1.714 & Good \\
\hline GFI & Above 0.90 & 0.764 & Not Good \\
\hline RMSEA & 0.05-0.08 & 0.066 & Good \\
\hline AGFI & Above 0.90 & 0.773 & Not Good \\
\hline TLI & Above 0.90 & 0.678 & Not Good \\
\hline NFI & Above 0.90 & 0.695 & Not Good \\
\hline PNFI & $0.60-0.90$ & 0.669 & Good \\
\hline PGFI & Above 0.90 & 0.763 & Not Good \\
\hline CFI & Above 0.90 & 0.736 & Not Good \\
\hline
\end{tabular}

Table 4 shows value of chi-square is 783.570 with probability 0.071 (above 0.05), value of RMSEA is 0.066 (below 0.08), value of TLI is 0.678 (below 0.9), value of CFI is 0.736 (below 0.9), and value of CMIN/ $\mathrm{DF}$ is 1.714 (below 2). It shows data model goodnessof-fit is good. Although values of TLI, CFI, and AGFI do not show good results, this research assumes that the model is still fit since the value of chi-square, RMSEA, and CMIN/DF already meet the SEM criteria (Ghozali, 2017).

\subsection{Hypothesis Testing and Discussion}

Table 5 shows that the probability of information system quality on information quality is 0.046 (below 0.05). It indicates $\mathrm{H} 1$ is supported. Information system quality has an effect on information quality. The result is consistent with Alannita and Suaryana (2014) who explain high-quality information systems relate to complete, relevant, accurate, and real-time information. A high-quality information system provides high-quality information for the user. A high-quality information system also helps the organization to allow complete, relevant, and accurate information to support their business. Based on confirmatory factor analysis, information reliability becomes the main concern for the organization in determining and choosing an ERP-based accounting information system. 
Table 5: Hypothesis Testing

\begin{tabular}{|l|c|l|c|c|c|c|c|}
\hline \multicolumn{2}{|l|}{ Path } & Estimate & S.E. & C.R. & P & Explanation \\
\hline Information Quality & $<---$ & Information System Quality & 0.259 & 0.130 & 1.999 & 0.046 & Supported \\
\hline Information Quality & $<---$ & Service Quality & 0.529 & 0.174 & 3.046 & 0.002 & Supported \\
\hline Perceived Usefulness & $<---$ & Information Quality & 0.029 & 0.064 & 0.462 & 0.644 & Rejected \\
\hline User Satisfaction & $<---$ & Information System Quality & -0.132 & 0.064 & -2.054 & 0.040 & Supported \\
\hline User Satisfaction & $<---$ & Service Quality & 0.520 & 0.146 & 3.556 & 0.000 & Supported \\
\hline User Satisfaction & $<---$ & Information Quality & 0.190 & 0.067 & 2.855 & 0.004 & Supported \\
\hline User Satisfaction & $<---$ & Perceived Usefulness & -0.297 & 0.105 & -2.823 & 0.005 & Supported \\
\hline Personal Skill & $<---$ & Training & -0.095 & 0.080 & -1.182 & 0.237 & Rejected \\
\hline Personal Skill & $<---$ & Knowledge Sharing & 0.127 & 0.064 & 1.984 & 0.047 & Supported \\
\hline Personal Skill & $<---$ & User Satisfaction & 1.008 & 0.263 & 3.827 & 0.000 & Supported \\
\hline Organizational Impact & $<---$ & Personal Skill & 0.528 & 0.131 & 4.025 & 0.000 & Supported \\
\hline
\end{tabular}

The probability of service quality on information quality is 0.002 (below 0.05). It indicates H2 is supported. Service quality has an effect on information quality. The result is consistent with Subiyanto (2000) who stated good service management can bring reliable, accurate, real-time, and effective information. A high-quality information system will not work effectively if there is no management support. Management can provide sufficient service on the use of information system software; further, it can contribute to generating high-quality information. Based on confirmatory factor analysis, facilities indicators give the biggest contribution to information system service. In other words, facilities become the main concern of the organization to improve service quality. High-quality service can bring highquality information, especially in ERP-based accounting information system implementation.

The probability of information system quality on user satisfaction is 0.040 (below 0.05). It indicates $\mathrm{H} 3$ is supported. Information system quality has an effect on user satisfaction. The result is consistent with Istianingsih and Wijanto (2008) and Tjakrawala and Cahyo (2010) who found information system quality has a positive effect on information system user satisfaction. Since a high-quality information system can meet user expectations, it gives satisfaction to the user. When the information system fails to meet user expectations, the user will feel no satisfaction.

The probability of service quality on user satisfaction is 0.000 (below 0.05). It indicates H4 is supported. Service quality has an effect on user satisfaction. The result is consistent with Parasuraman et al. (1985) who explained that expectation (satisfaction indicator) determines the service quality (perception of the service given). Service quality has an important role to improve information system success. When there is high service quality, the information system user gets a certain level of satisfaction. Since the main objective of service is to provide easiness, comfort, and satisfaction; high-quality information system service improves user satisfaction. Based on confirmatory factor analysis, the main concern of the organization is to bring sufficient facilities so user satisfaction can be achieved.

The probability of training on personal skill is 0.237 (above 0.05). It indicates $\mathrm{H} 5$ is rejected. There is no effect of training on personal skills. The result is not consistent with Medina et al. (2014) who found training increases employees' performance and satisfaction on information system implementation. The training program by the organization does not effectively succeed. Research respondents explain that training focuses more on practical skills than basic knowledge improvement. Since information system implementation is complex, a lack of basic knowledge brings less understanding for the user. Based on confirmatory factor analysis, user understanding gives the biggest contribution to the training effectiveness. It indicates that the training program can still not bring information system understanding to the user.

The probability of knowledge sharing on personal skill is 0.047 (below 0.05). It indicates H6 is supported. Knowledge sharing has an effect on personal skills. The result is consistent with Liao (2006) who found a significant relationship between organizational, knowledge sharing, and innovation. Knowledge sharing allows employees to get more knowledge where it can be used to improve their skills. Based on confirmatory factor analysis, the biggest contribution to knowledge sharing is when employees can share their experience and theory. 
The probability of information quality on perceived usefulness is 0.644 (above 0.05). It indicates $\mathrm{H} 7$ is rejected. There is no effect of information quality on perceived usefulness. The result is not consistent with Rivard et al. (1997), Roldán and Leal (2003), and Istianingsih and Wijanto (2008) who found that information quality can increase perceived usefulness. Based on confirmatory factor analysis, the biggest contribution to perceived usefulness is the easiness to understand. Since employees are trained more on practical aspects than the knowledge aspect, employees will see that there is no different quality from one type of information to another.

The probability of information quality on user satisfaction is 0.004 (below 0.05). It indicates $\mathrm{H} 8$ is accepted. Information quality has an effect on user satisfaction. The result is consistent with Seddon and Kiew (1996) who find that information quality increases user satisfaction. Highquality information can give benefit to the information system user. The benefit can fulfill the user's needs. The user feels satisfied when they can get what they need.

The probability of perceived usefulness on user satisfaction is 0.005 (below 0.05). It indicates $\mathrm{H} 9$ is supported. Perceived usefulness has an effect on user satisfaction. The result is consistent with Istianingsih and Wijanto (2008) and Tjakrawala and Cahyo (2010) who found that perceived usefulness increases user satisfaction. Information system implementation causes the user to have some perception. It depends on the benefits that the information system gives the user. The benefit of the information system leads to user satisfaction. User perception about how far information system can help the user will determine the user satisfaction. Higher perceived usefulness can increase user satisfaction.

The probability of perceived usefulness on personal skill is 0.000 (below 0.05). It indicates H10 is supported. Perceived usefulness has an effect on personal skills. The result is consistent with Seddon (1997) who stated that a useful information system can increase user competence. Satisfaction can bring motivation for employees to do their job well, further, employees' performance will be improved as well. When the user feels that the information system is useful, they are more likely to feel comfortable and safe, further, they can pull their skill out to work better.

The probability of personal skill on organizational impact is 0.000 (below 0.05). It indicates H11 is supported. Personal skills have an effect on organizational impact. The result is consistent with Seddon (1997), Davis (1989), DeLone and McLean (1992), Tjakrawala and Cahyo (2010), and Widodo et al. (2013) who found personal skills can increase organizational impact. Optimal personal skills can give positive consequences for organizational performance. The skill of information system implementation facilitates the user in decision-making.

\section{Conclusions}

The research objective is to examine information system implementation, user impact, and organizational impact. Based on data analysis, high-quality information system implementation generate high-quality information that can give satisfaction to the user. A useful information system also can give satisfaction to the user. Moreover, the information system is related to user skill, satisfaction, and knowledge sharing which improve personal skills; enhanced personal skill contributes to organizational performance. On the other hand, there is no effect of training on personal skills and there is no effect of information quality on perceived usefulness. This research gives implication to the organization for implementing a high-quality ERP-based accounting information system that positively impacts organizational performance. Future research is expected to examine information system implementation in different research objects and conditions.

\section{References}

Alannita, N. P., \& Suaryana, I. G. N. A. (2014). The effect of information technology sophistication, management participation, and technical capabilities of accounting information system users on individual performance. E-Jurnal Akuntansi Universitas Udayana, 6(1), 33-45.

Alter, S. (1996). Information systems: A management perspective (2nd ed.). San Francisco, CA: Benjamin/Cummings Publishing Company.

Bernardin, H. J., \& Russell, J. E. A. (1998). Human resource management: An experiential approach (2nd ed.). New York, NY: Irwin McGraw-Hill.

Bokhari, R. H. (2005). The relationship between system usage and user satisfaction: A meta-analysis. Journal of Enterprise Information Management, 18(2), 211-234. https://doi. org/10.1108/17410390510579927

Cash, J. I., McFarlan, F. W., \& McKenney, J. L. (1992). Corporate information systems management: text and cases (3rd ed.). New York, NY: Irwin McGraw-Hill

Choi, S. Y., Lee, H., \& Yoo, Y. (2010). The impact of information technology and transactive memory systems on knowledge sharing, application, and team performance: A field study. MIS Quarterly, 34(4), 855. https://doi.org/10.2307/25750708

Davis, F. D. (1989). Perceived usefulness, perceived ease of use, and user acceptance of information technology. MIS Quarterly, 13(3), 319. https://doi.org/10.2307/249008

DeLone, W. H., \& McLean, E. R. (1992). Information systems success: The quest for the dependent variable. Information Systems Research, 3(1), 60-95. https://doi.org/10.1287/ isre.3.1.60 
DeLone, W. H., \& McLean, E. R. (2003). The DeLone and McLean model of information systems success: A ten-year update. Journal of Management Information Systems, 19(4), 9-30. https://doi.org/10.1080/07421222.2003.11045748

Doll, W. J., Xia, W., \& Torkzadeh, G. (1994). A confirmatory factor analysis (CFA) of the end-user computing satisfaction instrument. MIS Quarterly, 18(4), 453. https://doi. $\operatorname{org} / 10.2307 / 249524$

Falgenti, K., \& Pahlevi, S. M. (2013). Evaluation of ERP information system success in small and medium enterprises: A case study: SAP B1 implementation at PT. CP. Jurnal Manajemen Teknologi, 12(2). https://doi.org/10.12695/jmt.2013.12.2.4

Gelinas, U. J., Dull, R. B., \& Wheeler, P. (2011). Accounting Information Systems. Boston, MA: Cengage Learning.

Ghozali, I. (2017). Structural Equation Modeling (SEM) concepts and applications with Amos Program 24. Indonesia: Badan Penerbit Universitas Diponegoro.

Gorla, N., Somers, T. M., \& Wong, B. (2010). Organizational impact of system quality, information quality, and service quality. The Journal of Strategic Information Systems, 19(3), 207-228. https://doi.org/10.1016/j.jsis.2010.05.001

Gupta, A. (2000). Enterprise Resource Planning (ERP): The emerging organizational value systems. Industrial Management \& Data Systems, 100(3), 114-118. https://doi. org/10.1108/02635570010286131

Haddon, L. (2016). The social dynamics of information and communication technology. London: Routledge. https://doi. org/10.4324/9781315552811

Hair, J. F., Black, W. C., Babin, B. J., \& Anderson, R. E. (2010). Multivariate data analysis. Upper Saddle River, NJ: Prentice-Hall.

Hall, J. A. (2010). Accounting information system (7th ed.). Boston, MA: South-Western Cengage Learning.

Hilbert, M., \& Lopez, P. (2011). The world's technological capacity to store, communicate and compute information. Science, 332(6025), 60-65. https://doi.org/10.1126/ science. 1200970

Hutahaean, J. (2014). Information system concept. Daerah Istimewa Yogyakarta, Indonesia: Deepublish.

Iivari, J. (2005). An empirical test of the DeLone-McLean Model of information system success. ACM SIGMIS Database, 36(2), 8-27. https://doi.org/10.1145/1066149.1066152

Istianingsih, \& Wijanto, S. H. (2008). The influence of information system quality, information quality, and perceived usefulness on accounting software user satisfaction. Simposium Nasional Akuntansi IX.

Kaihatu, T. S., Daengs, A., \& Indrianto, A. T. L. (2015). Complaints management. Indonesia: Penerbit Andi.

Krigsman, M. (2011). CIO analysis: Why 37 percent of projects fail. ZDnet: Beyond IT failure. https://www.zdnet.com/article/ cio-analysis-why-37-percent-of-projects-fail/
Liao, L. F. (2006). A learning organization perspective on knowledge-sharing behavior and firm innovation. Human Systems Management, 25(4), 227-236.

Lucas, H. C., Walton, E. J., \& Ginzberg, M. J. (1988). Implementing Packaged Software. MIS Quarterly, 12(4), 537-549.

Martono, S., Nurkhin, A., Mukhibad, H., Anisykurlillahh, I., \& Wolor, C. W. (2020). Understanding the employee's intention to use information system: Technology Acceptance Model (TAM) and Information System Success Model Approach (ISSMA). Journal of Asian Finance, Economics, and Business, 7(10), 1007-1013. https://doi.org/10.13106/jafeb.2020.vol7. no10.1007

Medina, J. M., Jimenez, K., Mora, A., \& Ábrego, M. S. D. (2014). Training in accounting information systems for users' satisfaction and decision-making. International Journal of Business and Social Science, 5(7), 134-144.

Miss, M. B. A. (2014). Information systems user satisfaction: A survey of the postgraduate school portal, University of Ibadan, Nigeria. Library Philosophy and Practice (E-Journal), 1, 5-10

Monk, E. F., \& Wagner, B. J. (2013). Concepts in enterprise resource planning (4th ed.). Boston, MA: Cengage Learning.

Nurlina, N., Situmorang, J., Akob, M., Quilim, C. A., \& Arfah, A. (2020). Influence of e-HRM and human resources service quality on employee performance. The Journal of Asian Finance, Economics, and Business, 7(10), 391-399. https://doi. org/10.13106/jafeb.2020.vol7.no10.391

O'Brien, J. A., \& Marakas, G. M. (2011). Management information systems (10th ed.). New York, NY: McGraw-Hill Education.

Otley, D. T. (1980). The contingency theory of management accounting: Achievement and prognosis. Accounting, Organizations and Society, 5(4), 413-428. https://doi. org/10.1016/0361-3682(80)90040-9

Parasuraman, A., Zeithaml, V. A., \& Berry, L. L. (1985). A conceptual model of service quality and its implications for future research. Journal of Marketing, 49(4), 41-50. https://doi. org/10.1177/002224298504900403

Pearlson, K. E., Saunders, C. S., \& Galletta, D. F. (2016). Managing and using information systems: a strategic approach. Hoboken, NJ: Willey.

Pramono, B. K., \& Susanty, A. I. (2016). The influence of personal factors, organizational factors, and technological factors in the use of CIM toward employees' knowledge sharing in PT. Jalan Tol Lingkar Luar Jakarta (PT. JTLJ). Proceedings of the 3rd International Seminar and Conference on Learning Organization (Isclo-15). https://doi.org/10.2991/ isclo-15.2016.8

Rahman, S., Nasir, M., \& Handayani, S. (2007). The effect of performance measurement systems on role clarity, psychological empowerment, and managerial performance (Partial Least Square Approach): Research on managers of manufacturing companies in Central Java). Simposium Nasional Akuntansi X. 
Rai, A., Lang, S. S., \& Welker, R. B. (2002). Assessing the validity of IS success models: An empirical test and theoretical analysis. Information Systems Research, 13(1), 50-69. https:// doi.org/10.1287/isre.13.1.50.96

Rivard, S., Poirier, G., Raymond, L., \& Bergeron, F. (1997). Development of a measure to assess the quality of userdeveloped applications. The Database for Advances in Information Systems, 28(3), 44-58. https://doi. org/10.1145/272657.272690

Roldán, J. L., \& Leal, A. (2003). A validation test of an adaptation of the DeLone and McLean's Model in the Spanish EIS field. In: J. J. Cano (ed.), Critical reflections on information systems (pp. 66-84). Hershey, PA: IGI Global. https://doi.org/10.4018/978$1-59140-040-0$

Seddon, P. B. (1997). A respecification and extension of the DeLone and McLean Model of IS success. Information Systems Research, 8(3), 240-253. https://doi.org/10.1287/isre.8.3.240

Seddon, P., \& Kiew, M. Y. (1996). A partial test and development of Delone and Mclean's model of IS success. Australasian Journal of Information Systems, 4(1). https://doi.org/10.3127/ ajis.v4i1.379

Shannon, C. E. (1948). A mathematical theory of communication. Bell System Technical Journal, 27(3), 379-423. https://doi. org/10.1002/j.1538-7305.1948.tb01338.x

Simkin, M. G., Norman, C. S., \& Rose, J. M. (2015). Core concepts of accounting information systems (13th ed.). Hoboken, NJ: Willey.

Subiyanto, I. (2000). Management and accounting research methodology. Yogyakarta City, Indonesia: UPP AMP YKPN.

Susanto, A. (2013). Accounting information system. Indonesia: Lingga Jaya.

Tjakrawala, F. X. K., \& Cahyo, A. (2010). Adaptation of modified DeLone \& McLean models to test the success of accounting software implementation for individual users: Empirical study of companies in the consumer goods industry listed on the IDX. Simposium Nasional Akuntansi XIII.

Tjini, S. S. A., \& Baridwan, Z. (2013). The influence of trust, perceived usefulness, perception of convenience, and perception of convenience on interests in using the Internet banking system. Jurnal Ilmiah Mahasiswa FEB, 1(2), 1-21.

Tran, N., Le, T., Nguyen, L., Hoang, L., \& Nguyen, T. (2020). Factors influencing technology adoption in Vietnam's educational system. Journal of Asian Finance, Economics, and Business, 7(10), 347-357. https://doi.org/10.13106/jafeb.2020. vol7.n10.347

Triana, A., Utami, H. N., \& Ruhana, I. (2016). The effect of organizational communication on knowledge sharing and employee performance (Studies on employees of hotel Gajah Mada Graha Malang). Journal Administrasi Bisnis, 35(2), 86-93.

Watson, R., Pitt, L., \& Kavan, C. (1998). Measuring information systems service quality: Lessons from two longitudinal case studies. MIS Quarterly, 22(1), 61-79.

Widodo, T. W., Handayani, S. R., \& Saifi, M. (2013). The effect of management information system application on employee performance (Case study in small and medium enterprises in the internet cafe business in Malang city). Profit: Journal Administrasi Bisnis, 7(1), 87-100.

Wu, J. H., \& Wang, Y.-M. (2007). Measuring ERP success: The key-users' viewpoint of the ERP to produce a viable IS in the organization. Computers in Human Behavior, 23(3), 15821596. https://doi.org/10.1016/j.chb.2005.07.005

Xiao, L., \& Dasgupta, S. (2002). Measurement of user satisfaction with web-based information systems: An empirical study. In: Americas Conference on Information Systems.

Xu, D. J., Benbasat, I., \& Cenfetelli, R. T. (2013). Integrating service quality with system and information quality: An empirical test in the E-Service context. MIS Quarterly, 37(3), 777-794. https://www.jstor.org/stable/43825999 